\title{
内視鏡下に切除しえた鼻中隔軟骨肉腫例
}

\author{
小澤 聡美, 安田＼cjkstart誠, 鯉田 篤英, \\ 大西 俊範, 乾隆昭, 平野滋 \\ 京都府立医科大学耳鼻咽喉科·頭頸部外科学教室
}

\begin{abstract}
軟骨肉腫のうち頭頸部領域に発生するものは全体の 1 ～12\%であり，鼻中隔に発生するものは稀である。軟 骨肉腫は放射線療法や化学療法の感受性が一般に低いとされ，外科的切除が基本となる。我々は鼻中隔に発生 した軟骨肉腫の 1 例を経験した。症例は 56 歳男性, 主訴は左鼻閉であった。CTで鼻中隔後方に最大径 $36.5 \mathrm{~mm}$ の内部斑状の石灰化を伴う腫瘤を認めた。前医での生検で軟骨腫瘍の疑いにて当科紹介となり, 当院で再検討 し軟骨肉腫の診断となった。本症例は低悪性度の軟骨肉腫が疑われたこと, 術前の画像診断で頭蓋底への進展 を認めなかったことより, 内視鏡操作で安全域をつけて切除可能と判断したため術前に腫瘍の栄養血管塞栓術 を行い, 術中迅速病理診断を利用することにより分割切除で内視鏡下に腫瘍を摘出した。本症例では現在術後 2 年経過しているが，再発や転移は認めていない。
\end{abstract}

キーワード : 軟骨肉腫, 鼻中隔, 内視鏡下切除

\section{A Case of Chondrosarcoma in the Nasal Septum Successfully Treated with Endoscopic Resection}

\author{
Satomi Ozawa, Makoto Yasuda, Atsuhide Koida, Toshinori Onishi, Takaaki Inui, Shigeru Hirano
}

Department of Otolaryngology-Head and Neck Surgery, Kyoto Prefectural University of Medicine

Chondrosarcoma in the head and neck accounts for $1-12 \%$ of all chondrosarcomas and chondrosarcoma arising in the nasal septum is rare. Here, we reported a case of chondrosarcoma in the nasal septum in a 56 -year-old man who presented with left nasal obstruction for 1 year. The standard treatment for this tumor is surgical resection, because radiation therapy and chemotherapy have limited roles. Recently, it has been reported that nasal chondrosarcoma could be removed by an endoscopic approach, which has advantages of improved cosmetic appearance and early discharge. Our case did not have evidence of skull base invasion due to intracranial extension, and was considered as a low grade malignancy therefore we resected the tumor via endoscopic approach by use of piecemeal resection. Utilizing the intraoperative frozen section pathological diagnosis, complete tumor resection was finally achieved. There has been no recurrence for 2 years postoperatively. We considered that chondrosarcoma in the nasal septum being low grade malignancy without skull base involvement like our case could be removed by an endoscopic approach.

Key words : chondrosarcoma, nasal septum, endoscopic resection 


\section{1.はじめに}

軟骨肉腫のうち頭頸部領域に発生するものは全体の 1 $12 \%$ である ${ }^{1)}$ 。放射線療法や化学療法の感受性が一般 に低いとされ，外科的切除が基本となる。今回我々は内 視鏡下に切除しえた鼻中隔軟骨肉腫の 1 例を経験したた め文献的考察を加えて報告する。

\section{2. 症例}

症例：56歳男性

主訴：左鼻閉

既往歴：狭心症，糖尿病，高血圧症，高脂血症 嗜好歴：喫煙 50 本 $/$ 日 $\times 26$ 年, 飲酒機会飲酒 現病歴： 1 年前からの左鼻閉にて近医耳鼻咽喉科を受 診した。副鼻腔炎として加療されるも改善はなかった。
そこで副鼻腔単純 X線にて左鼻腔病変を指摘され, 精査 加療目的に前医を紹介受診した。前医で全身麻酔下に生 検を施行され, 軟骨腫瘍の疑いにて精查加療目的に当科 を紹介受診した。

現症：両側鼻中隔後端に表面平滑な腫瘤があり，左後 鼻孔は閉塞していた（図1A，B）。その他，耳鼻咽喉科 領域に特記事項は認めなかった。

画像所見では単純CTにて後鼻孔に最大径 $36.5 \mathrm{~mm}$ の 境界明膫な腫瘤があり，腫瘤の中心部には斑状の石灰化 を認めた。圧排性骨変化が主体で骨破壊は軽度のみで あった。蝶形骨洞前壁・下壁・左翼口蓋窩とは接してい るが周囲の骨変化はなく，頭蓋底および眼窩内への進展 は認めなかった（図2)。MRIではT1 強調画像で低信号, T2 強調画像で高信号を呈し，Gdでは辺縁および内部の 一部がまだらに造影されていた（図3)。PET-CTでは局
A

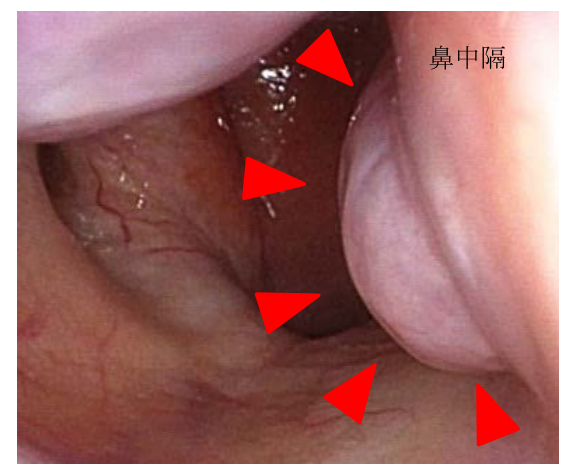

B

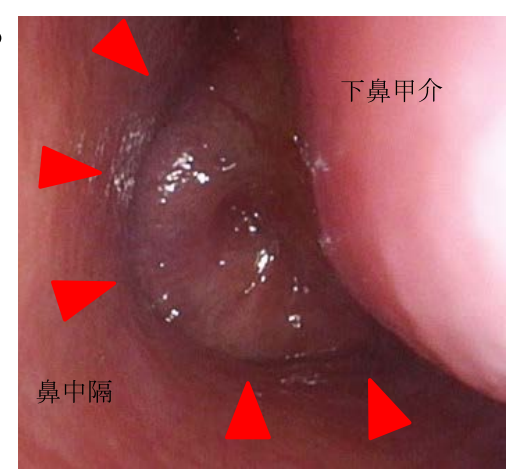

図1 A 右鼻腔。鼻中隔後端に表面平滑な腫瘤を認めた。 $\mathrm{B}$ 左鼻胿。鼻中隔後端に表面平滑な腫瘤 あり，後鼻孔は閉塞していた。
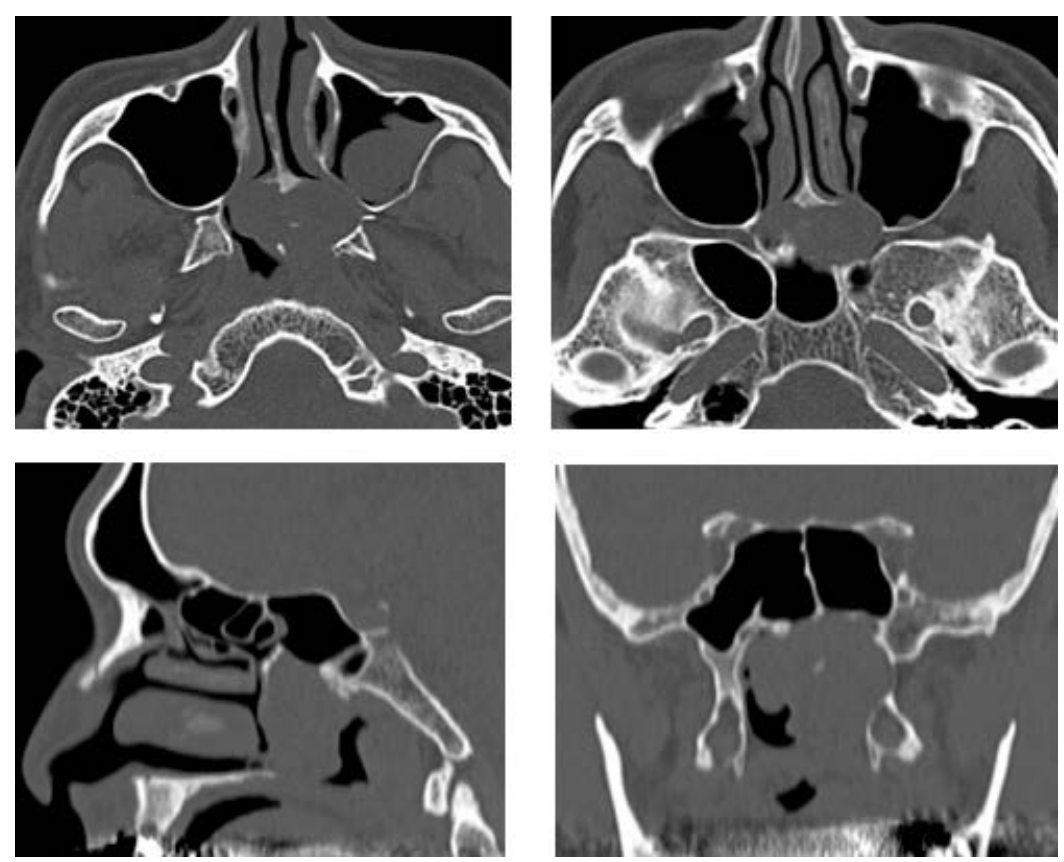

図2 単純 $\mathrm{CT}$ 。後鼻孔に腫瘤を認め, 周囲の圧排性骨変化，腫瘤の中心部には玟状の石灰化を認めた。 
所の淡い集積のみで, 頸部・遠隔藏器にFDG集積は認め なかった。以上より，画像上は低悪性度の腫瘍と考えら れた。

前医で採取した組織を当院で再検討したところ，画像 所見とあわせて鼻中隔軟骨肉腫 grade I, 鼻腔内に限局し 頭蓋底や眼窩内に進展なし，頸部リンパ節転移・遠隔転 移なしと判断し，手術目的に当科入院となった。内視鏡 操作で安全域をつけて切除可能と考え, 内視鏡下に腫瘍 摘出することとした。

内視鏡下手術を行うにあたって術中の出血の抑制とよ
りよい視野の確保のために栄養血管塞栓術を施行した。 手術前日の午後に血管造影を施行し, 両蝶口蓋動脈から 腫瘍が濃染されることを確認できたため, 両側の蝶口蓋 動脈の血管塞栓術を施行した。手術は最初に左ESS と左 endoscopic medial maxillectomy (EMM) を行い, 腫瘍 の左後側方の視野を確保した。腫瘍は左後鼻孔を占拠 する形で存在し，被膜を有し周囲との境界は明暸で，視 診上内側翼突板や上顎洞後壁への浸潤は認めなかった (図4A)。これらの部位を腫瘍切除前に術中迅速病理診断 に提出し腫瘍細胞が存在しないことを確認し，翼突筋や
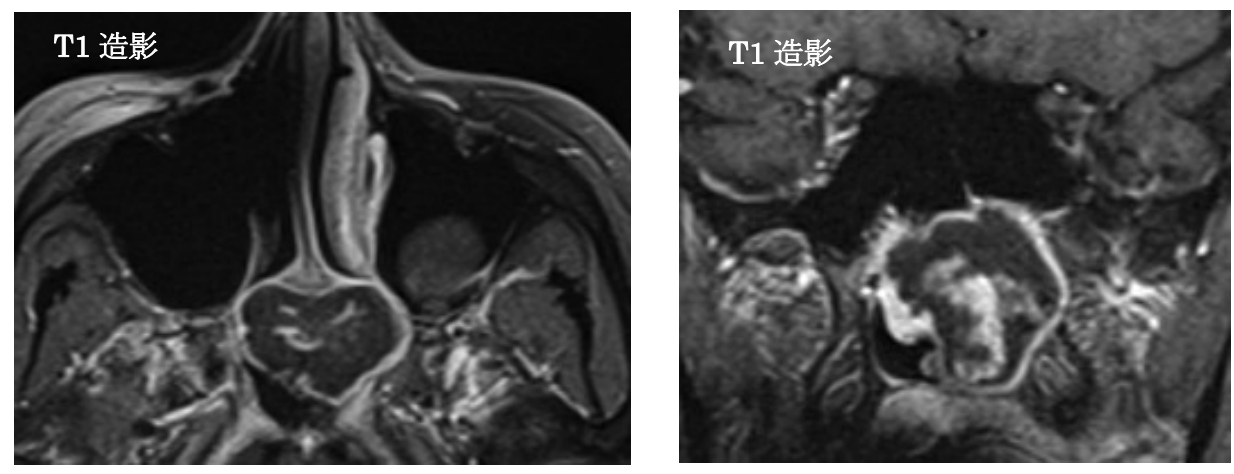

図3 造影MRI。辺縁および内部の一部に造影効果を認めた。
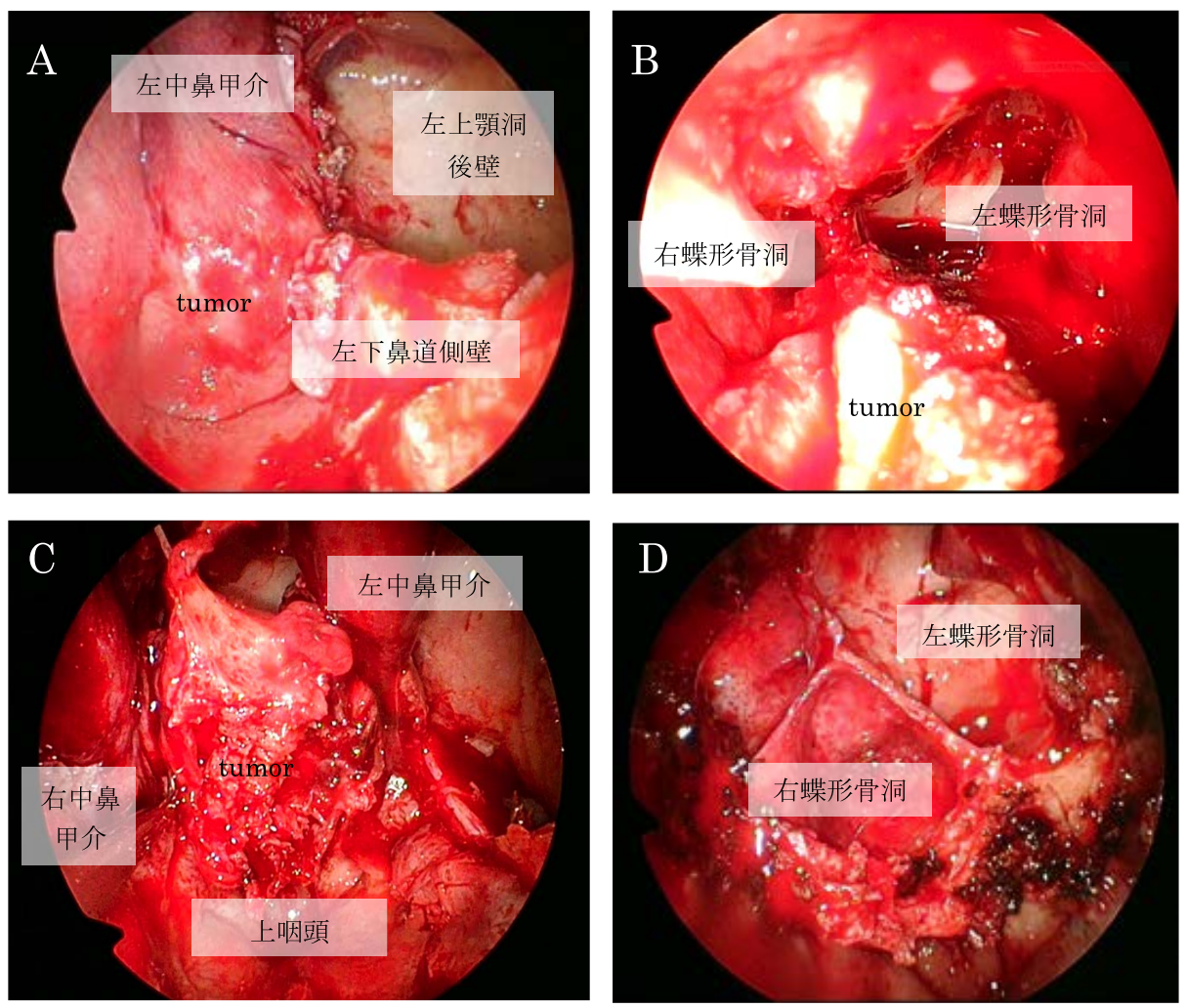

図4 A EMM後, 腫瘍左外側後端部。腫瘍は被膜を有しており周囲への浸潤は認めなかった。 B 腫瘍上方切除後 後端部。鼻中隔上方から腫瘍頭側を分割切除しながら後方へ進み両側蝶形骨洞に到達した。C 後端部残存腫 瘍。鼻中隔後端と蝶形骨洞前面に腫瘍を残存させ最終的な腫瘍切除を行った。D 手術終了時蝶形骨洞。鼻腔 後方では4-handed surgeryで蝶形骨洞を開放していき，腫瘍を完全切除した。 
翼口蓋窩は露出させずに腫瘍の分割切除を開始した。次 に鼻中隔前方の操作に移った。内視鏡を用いて腫瘍前端 を確認したところ鼻中隔前方には正常粘膜があり，腫瘍 より $5 \mathrm{~mm}$ 程度の安全域をつけて前方切除線を決定した。 両側正常鼻粘膜に切開を加え, 腫瘍の頭側から分割切除 を開始し，両側蝶形骨洞まで到達した（図4B）。鼻中隔 前方切開部より視診上腫瘍浸潤のない鼻中隔下方から鋤 骨を露出させ，これを尾側断端とした。鋤骨を骨削開し ながら分割切除を後方に進め, 蝶形骨洞前面に腫瘍を集 束させた（図 $4 \mathrm{C}$ )。腫瘍後方切除に移る前に左右の蝶形 骨洞外側の粘膜を術中迅速病理診断に提出し, 腫瘍細胞 がないことを確認した。右側はこれを側方限界とし，左 側は安全域を確保するため翼突管を開放してVidian神経 を切断し, 翼状突起基部も一部骨削開した。4-handed surgeryの要領で手術を続け, 視診上腫瘍浸潤のない蝶 形骨洞前・下壁の骨削開を行った。最終的に左右の蝶形 骨洞を大きく開放し腫瘍を全切除した（図4D）。なお切 除終了後に腫瘍が後方で近接していた蝶形骨洞粘膜と上 咽頭前壁粘膜を後方断端として術中迅速病理診断で腫瘍 の残存がないことを確認し終了した（図5A-C)。な打腫
瘍切除時にはバイポーラシザーズを用いて止血を入念に 行った。手術時間は 6 時間 52 分, 出血量は $265 \mathrm{~g}$ であった。

摘出標本の病理所見は小葉状の軟骨硝子基質に高い細 胞密度で膨隆した二核細胞が多数存在し，一部では核の 空胞化も目立っていた(図6)。術前の生検結果ではgrade Iであったが，全体としての細胞密度・細胞異型より摘出 標本は grade II と診断した。合併症なく, 術後6日目で 退院となった。術後6ケ月の鼻䏕所見・MRIでは再発を 疑う所見は認めなかった（図 7 )。現在術後 2 年経過する が，再発・転移なく経過良好である。

\section{3. 考察}

軟骨肉腫は腫瘍性の軟骨形成を伴うが, 腫瘍性の類骨· 骨形成を伴わない非上皮系の悪性骨腫瘍と定義される。 原発性悪性骨腫瘍の中で骨肉腫に次いで頻度が高く，全 墨性骨腫瘍の 10～20\%であり全骨軟部腫瘍の $4 \%$ を占め るが, 頭頸部領域に発生する全悪性腫瘍のうち $0.2 \%$ に過 ぎない ${ }^{1,2)}$ 。好発部位は骨盤・肋骨などの体幹骨や大腿骨 および上腕骨であり，頭頸部領域に発生するものは 1 $12 \%$ ある。頭頸部領域では喉頭に発生するものが最も
A

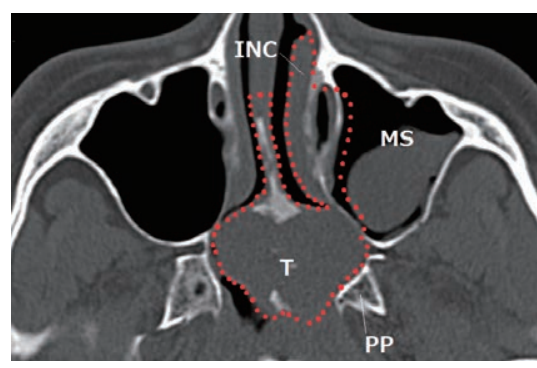

$\mathrm{B}$

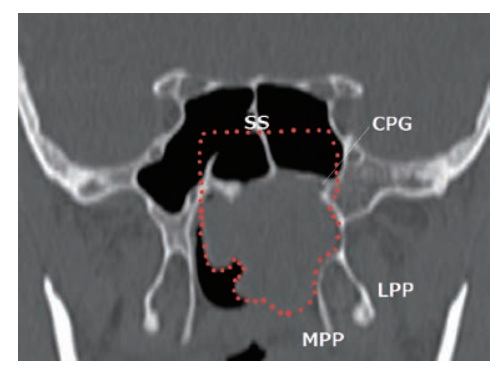

$\mathrm{C}$

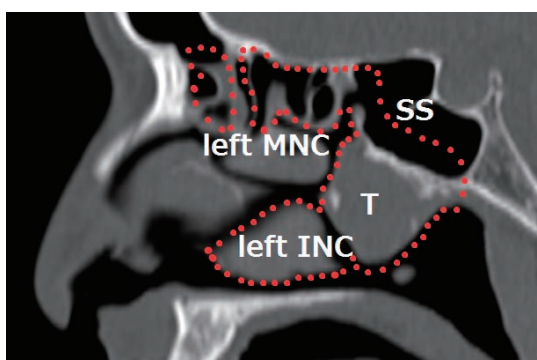

図5 切除範囲。 CPG：翼突管, INC：下鼻甲介, LPP : 外側翼突板, MNC : 中鼻甲介, MPP：内側翼突板, MS : 上顎洞, PP： 翼状突起, SS : 蝶形骨洞, T ：腫場。赤の点線は切除範囲を示す。

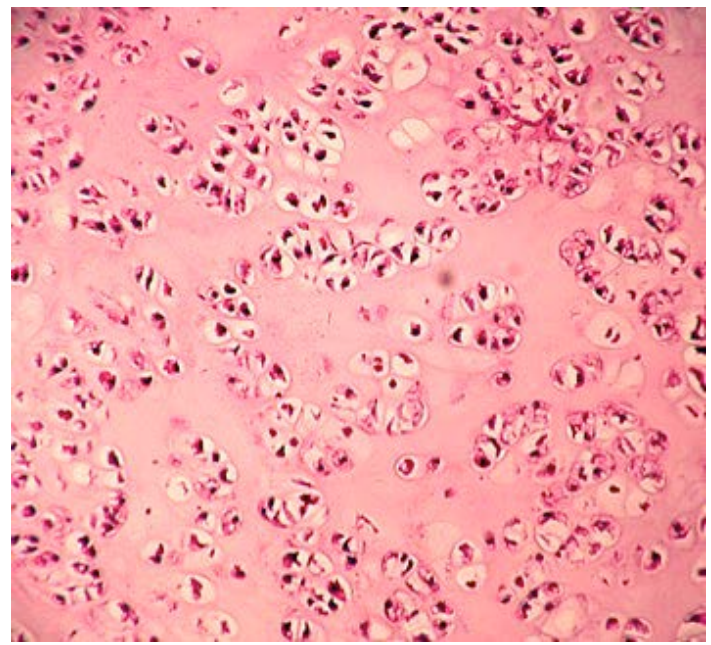

図6 手術摘出標本の病理組織。H.E.染色 $(\times 100$ 倍 $)$

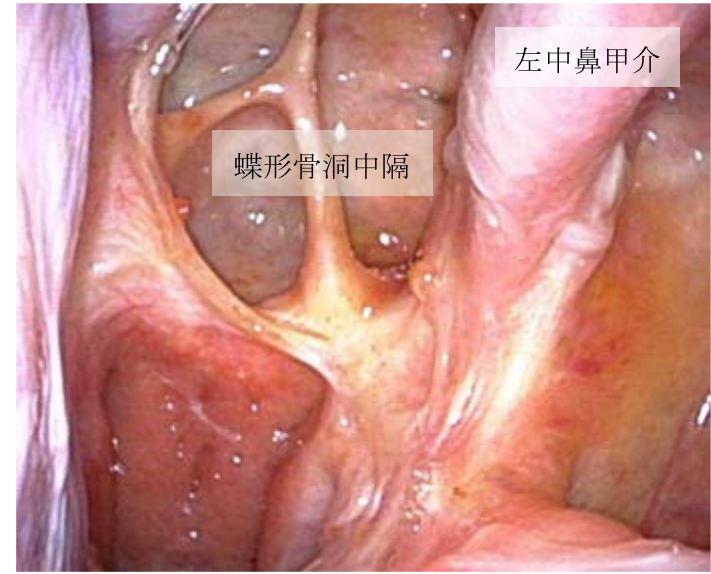

図7 術後鼻内所見。鼻腔内に再発所見を認めない。 
多く，次に鼻腔，下顎骨，上顎骨と続き，鼻中隔に発生 するものは稀である ${ }^{1,3)}$ 。好発年齢は 30～60歳代で, 性差 はやや男性に多い。頭頸部領域に発生する軟骨肉腫にお いても男性にやや多いが，他部位に発生する軟骨肉腫と 比較すると，好発年齢はわずかに頭頸部領域に発生する 軟骨肉腫の方が若い1)。

確定診断は病理組織診断となり，核の大きさ・細胞間 質の状態・細胞密度・有糸分裂像の有無を基準に grade I 〜 IIIに分類される。Grade分類と遠隔転移, 予後が相 関しているとされており,遠隔転移率はgrade Iでは稀で あり, grade IIでは10〜15\%, grade IIIでは $50 \%$ 以上と 報告されている 腫の方が他部位発生例より low grade, low stageであり, 予後も良好であったという報告もある1)。本症例では生 検した組織標本では grade Iの診断となったが, 摘出した 組織標本ではgrade Iを呈する部位とgrade IIを呈する部 位とが混在していたため grade IIの診断となった。これは 軟骨肉腫の組織が均一ではないことが原因と考えられる5 。 また, grade Iの軟骨肉腫は良性の軟骨腫に似た軟骨基質 を有することから組織学的な鑑別がしばしば困難であ る ${ }^{4)}$ 。以上より腫瘍のごく一部だけの生検では診断が難 しく確定診断には十分な量の検体が必要となり, 生検材 料のみでなく画像や臨床経過からの判断も重要となる。

一般に軟骨肉腫は CTでは等〜低吸収で造影効果はそ しく, 腫瘍中心部に小結節あるいは斑点状の石灰化を認 める。MRIでは硝子軟骨や粘液様変性を反映してT2強 調像で高信号を呈し, Gdで辺縁や隔壁様構造が分葉状に 造影される。覀性度の高い例では浸潤性の骨破壊像が認 められ，石灰化は乏しいとされている6。 また $\mathrm{T} 1$ 強調像 で中心領域に高信号, Gdにて中心に造影されない領域が 存在することが悪性度の高い症例の特徴であったとの報 告もある7”。本症例では腫瘍の中心に斑状の石灰化を認 め, 周囲骨も圧排性変化が主体で破壊性変化は軽度のみ であり画像上は低悪性度の腫瘍と考えられた。

軟骨肉腫は放射線療法や化学療法に対して抵抗性があ ると考えられており, 外科的切除が最も有効な治療手段 とされる ${ }^{2}$ 。近年鼻副鼻腔腫瘍において内視鏡下手術で 摘出する例が増えている。内視鏡下手術は顔面皮虐切開 を加えないため整容面に扔いて有利であり, 外切開に比 べて低侵襲となり入院期間の短縮も期待できる。適応拡 大している背景として, 様々な視野方向の内視鏡カメラ・ デブリッター・ナビゲーションシステムなど周辺機器の 著しい進歩により危険部位を回避でき安全に手術可能と なったためと考えられる ${ }^{8}$ 。頭頸部腫瘍全般において外 科的切除の原則は「十分な安全域をつけた一塊切除」で
あるが, 鼻副鼻腔は眼窝や視神経, 頭蓋底など重要な臟 器が隣接しているため十分な安全域をつけにくく, 鼻副 鼻腔腫瘍は内視鏡下に一塊に切除できないことも少なく ない。一方, 軟骨肉腫においては, 低悪性度で全貌が内 視鏡下に確認でき頭蓋底の骨浸潤がない症例が内視鏡下 切除のよい適応とされており ${ }^{9)}$, 分割切除で局所制御が 十分可能であるとの報告もある ${ }^{10)}$ 。本症例でも術前の画 像所見・病理組織からは低悪性度の軟骨肉腫と判断でき, また頭蓋底にも浸潤は認めず，腫瘍後端部に当たる鼻中 隔後端から蝶形骨洞前面は内視鏡下に安全域をつけて 切除可能と考え，内視鏡下に摘出する方針とした。鼻副 鼻腔腫瘍の切除に関しては腫瘍の基部となる部分以外を 分割切除し基部のみ安全域をつけて切除する multilayer centripetal techniqueが近年提唱されている ${ }^{11}$ 。本法は有 茎性の比較的柔らかい腫瘍を対象としたものであり，自 験例のような基部が不明瞭で硬い腫瘍にはそのまま適応 することは困難である。今回我々は十分に止血をした上 で分割切除を行い, 最終的に残存した深部病変に対して 解剖学的に一塊切除は不可能であったため分割切除を 行ったが, 切除前後に入念に margin studyを行い手術の 根治性が上がるように心掛けた。厳密には multilayer centripetal technique とは異なるが, 手術の conceptには 類似性があると考えている。

内視鏡下に安全かつ確害に手術をするにあたり，出血 のコントロールが重要であると考え, 出血量を減少させ 手術時間を短縮するために術前に血管塞栓術を行った。 血管塞栓術の重篤な合併症として脳塞栓症 - 視力言失 · 脳神経麻疩・皮膚壊死があげられるが ${ }^{12}$, 本症例では5 56 歳と比較的若年であり，患者にリスクを説明の上術前に 栄養血管塞栓術を行うこととした。ただし造影MRIでは 腫瘍造影効果はそしくまた栄養血管は蝶口蓋動脈と予想 できたため，血管塞栓術は行わずに術中に出血が多く なった時点で腫瘍進展のない翼口蓋窩から顎動脈の分枝 を結紮することで，止血処置ができた可能性がある。た だ血管結禁術の場合，術中に十分なworking space と出 血のないきれいな術野を確保する必要があり，手術時間 が延長する可能性がある。今後同様の症例があれば術前 血管塞栓術か術中血管結紫術のどちらを行うかは入念に 検討すべき課題と考えている。

本疾患は初回の治療後 20 年以上経過を経た再発例の報 告もある ${ }^{13)}$ 。本症例も現在再発・転移は認めないが, で きるだけ長期の経過観察が必要と考えている。手術単独 では制御が困難と考えられる例や再発例に対して, 近年 重粒子線治療を行ったという報告が増えている。骨軟部 腫瘍に対する重粒子線治療の前向き試験として, 切除不 
適応と判断され重粒子線治療を受けた骨軟部腫瘍57症例 （骨腫瘍 41 例，軟部組織腫瘍 16 例）の解析で 3 年局所制 御率は $73 \% ， 3$ 年全生存率は $46 \%$ と既存の治療方法を超 える成績が報告された ${ }^{14)}$ 。また頭蓋底軟骨肉腫において, Feuvretらは術後high-dose 陽子線治療は低い副作用で 高い局所制御率の結果が得られたとも報告している ${ }^{15)}$ 。 今後軟骨肉腫を含む骨軟部腫瘍の治療の中で重粒子線治 療が大きな役割を果たしていく可能性があり，本症例の 再発時にも切除不能であれば考慮すべき治療法と考えて いる。

\section{4. まとめ}

鼻中隔に発生した軟骨肉腫の 1 例を経験した。画像所 見・病理組織より低悪性度であり，また頭蓋底に浸潤を 認めなかったことから内視鏡下に摘出する方針とした。 術中迅速病理診断を切除線の決定のため利用することに より分割切除であっても内視鏡下に安全かつ確実に摘出 することができた。2年経過した現在再発・転移を疑う 所見は認めないが，引き続き長期的に経過観察する必要 がある。

\section{参考文献}

1) Ellis MA, Gerry DR, Byrd JK : Head and neck chondrosarcoma: Analysis of the Surveillance, Epidemiology, and End Result database. Head Neck 2016 ; 38 : 1359-1366.

2) Kutzner EA, Park JS, Zaheer S, et al : Tracheal chondrosarcoma: Systematic review of tumor characteristics, diagnosis, and treatment outcomes with case report. Case Rep Oncol Med 2017 ; 2017 : 4524910

3) Magnano M, Boffano P, Machetta G, et al : Chondrosarcoma of the nasal septum. Eur Arch Otorhinolaryngol $2015 ; 272$ : 765-772.

4) Evola FR, Costarella L, Pavone V, et al : Biomarker of osteosarcoma, chondrosarcoma, and ewing sarcoma.
Front Pharmacol $2017 ; 150: 1-14$.

5）村川哲也, 唐帆健浩, 山内宏一, 他：輪状軟骨原発 喉頭軟骨肉腫の一例. 日気食会報 $2004 ; 55: 29-35$.

6）藤井正彦，岩間祐基，小西淳也，他：骨腫瘍の画像 診断. 日放技学誌 $2003 ; 59: 206-208$.

7) Yoo HJ, Hong SH, Choi JY, et al : Differentiating high-grade from low-grade chondrosarcoma with MR imaging. Eur Radiol 2009 ; 19 : 3008-3014.

8）花澤豊行：内視鏡下鼻内手術の基礎. 日鼻誌 2013 ; $52: 119-120$.

9) Carrau RL, Aydogan B, Hunt JL : Chondrosarcoma of the sphenoid sinus resected by an endoscopic approach. Am J Otolaryngol $2004 ; 25$ : 274-277.

10) Steinbichler TB, Kral F, Rinold $S$, et al : Chondrosarcoma of the nasal cavity in a patient with Maffucci syndrome: Case report and review of the literature. World J Surg Oncol $2014 ; 12: 387$.

11）花澤豊行, 山崎一樹, 大木雄示, 他 : 経鼻内視鏡下 手術を行った鼻副鼻腔悪性腫瘍症例の臨床的検討. 頭頸部外科 $2014 ; 24: 249-253$.

12）大須賀慶悟, 平吹度夫, 中村仁信, 他 : 頭頸部腫瘍 性病変の塞栓術 頭頸部領域のIVR（解説/特集). Interventional Radiology $2001 ; 16: 11-17$.

13) Kaufman JK, Pritz MB, Righi PD, et al : Craniofacial resection of a nasoseptal chondrosarcoma: Case report and review of literature. Surg Neurol $1999 ; 52$ : 265-269.

14) Kameda T, Tsuji H, Tsuji H, et al : Efficacy and safety of carbon ion radiotherapy in bone and soft tissue sarcomas. J Clin Oncol $2002 ; 20$ : 4466-4471.

15) Feuvret L, Bracci S, Calugaru V, et al : Efficacy and safety of adjuvant proton therapy combined with surgery for chondrosarcoma of the skull base: A retrospective, population-based study. Int J Radiat Oncol Biol Phy 2016 ; 95 : 312-321. 